\title{
砕波指標の整理について
}

\section{A SYNTHESIS OF BREAKER INDICES}

$\begin{array}{llr}\text { 合 } & \text { 田 良 } & \text { 実* }^{*} \\ \text { By } & \text { Yoshimi } & \text { Goda }\end{array}$

\section{1. ま え がき}

海岸に寄せては砕け，砕けては引く海の波は，いつ見 ても興味のつきないものであろう。しかし，海岸や港湾 の工事にたずさわる者にとって，海の波は第 1 に考えな ければならない外力であり, その大きさは構造物の設 計, 施工を直接に左右する。なかでも砕波は, 波力とし ても最大の力を発揮するため，その起こる位置と波高を 推定することは, 設計の重要な手順となる。このため砕 波に関する理論, 実験, 現地観測は数多く行なわれてお り,こうした結果からいくつかの砕波指標が提案され, 実用に供されている。

砕波指標の中では 1944 年に米国海軍水路部から発 表されたもの ${ }^{1)}$ が最初と思われ，とくに米国の Beach Erosion Board によって海岸工学の技術者に紹介 ${ }^{2}$ され て以来, 広く知られているもので, 単に砕波指標といえ ばこれを指すことが多い。この砕波指標は, 主として観 測值に基づくもので, 図表の形にまとめられているが, 1949 年に $\mathrm{Munk}^{3)}$ は孤立波理論に基づくつぎの関係式 を示している。

$$
\begin{aligned}
& \frac{H_{b}}{H_{0}}=\frac{1}{3.3 \sqrt[3]{H_{0} / L_{0}}} \cdots \cdots \cdots \cdots \cdots \cdots \cdots \cdots \cdots \cdots \cdots \cdots \cdots \cdots \\
& \frac{h_{b}}{H_{b}}=1.28 \quad\left(\text { または } \frac{H_{b}}{h_{b}}=0.78\right) . \cdots
\end{aligned}
$$

ここに, $H_{b}$ : 砕波高, $h_{b}$ : 砕波水深, $H_{0}$ : 沖波波高, $L_{0}$ : 沖波波長, であるた Munk は実駼值および観測值 と比較して, データのばらつきは大きいけれども, 平均 的には式 (1)，（2）が合うとしており，米国の海岸工 事の設計指針) では，主にこれを採用している。

この二つの砕波指標では海底勾配の影響が取り入れら れていないが，その後間もなく海底勾配が急なときには

* 正会員 運輸省港湾技術研究所水工部

† 本報告に用いた記号のうち主要なものは本文最後に一括し て示した。
砕波高が大きいことが認められ5)，米国のカリフォル ニア大学などで系統的な実験が行なわれ，この結果が Iversen の実験曲線 として 1951，1952 年に発表され $た^{(6), 7)}$ 。

以上 3 種の砕波指標は, 砕波諸元と沖波の諸元との関 係を表わすものである。一方, 硅波限界にある波の特性 については早くから研究が行なわれており, 樑海波の砕 波に関しては, 1893 年に Michell ${ }^{8)}$ が $\left(H_{0} / L_{0}\right)_{b}=0.142$ と計算し, また浅海波の極限としての孤立波について は, 1894 年に $\mathrm{McCowan}^{9)}$ が $(H / h)_{b}=0.78$ の值を示 している。この二つの極限の中間にある浅海表面波につ いては, 1944 年に Miche ${ }^{10)}$ が次式を導いている。

$$
\left(\frac{H}{L}\right)_{b}=0.142 \tanh 2 \pi\left(\frac{h}{L}\right)_{b} \cdots
$$

また, 浜田 $\left.{ }^{11}\right)$ Miche とは別に同じ式を導き, 実験で その妥当性を検証している。さらに, Suquet と Wa$\operatorname{llet}^{12)}$ は一様水深における砕波限界の実験曲線を 1953 年に発表している。

その後, 砕波に関する研究は数多く行なわれ, また他 の問題に関する研究の一環として砕波を扱って実験デー 夕を発表したものも多数あり, 砕波に関するデータの蓄 積は著しい。しかしながら, これらのデータも相互に比 較してみると, かなりの不一致が目につく。たとえば, 前述の米国水路部の研波指標, Munk の孤立波理論, および Iversen の実験曲線は, 標準的な砕波指標として 多くの参考書に記載されているが, この 3 種の指標にし ても碎波高や砕波水深に $20 \%$ 以上の差を示す場合があ る。こうした砕波指標の不一致は, 砕波現象の変動性を そのままに表わしているといえるけれども，使用する立 場から見れば誠に不統一で，どれを採用すべきか判断に 苦しむところである。また, Iversen の曲線では, 研波 高が浅海における微小振幅波としての波高まりも小さい 場合が出てくる。たとえば, $T=9 \mathrm{sec}, H_{0}=5 \mathrm{~m}$ とする と $H_{0} / L_{0} \fallingdotseq 0.04$ であるから, 海底勾配が $1 / 50$ 以下の ときは水理公式集 (昭 38 版) ${ }^{13)}$ の図一 $2.21,2.22(\mathrm{pp}$. 
481 482) によって, $H_{b} / H_{0}=0.94, h_{b} / H_{0}=1.11$ とな り,これから $H_{b}=4.7 \mathrm{~m}, h_{b}=5.6 \mathrm{~m}$ の值が得られる。 しかし, $T=9 \mathrm{sec}$ の沖波が $h=5.6 \mathrm{~m}$ の浅海に進んだ ときは, 水深の変化によって波高が $K_{s}=1.04$ 倍, 寸な わち $H=5.2 \mathrm{~m}$ になるはずであり, $H_{b}=4.7 \mathrm{~m}$ は過小 な推定值である。

このような砕波データの不一致や矛盾をそのままにし ておくのは実用上好ましくないので, 著者は最近の研究 成果などを参照して砕波データの整理を行ない，あまり 矛盾の生じない砕波指標を作成したので，ここに報告す る次第である。

\section{2. 砕波点における波の特性}

\section{（1）砕波限界波高}

砕波の大きさに関する問題は, 沖波の諸元との関係と して捉える場合と, 特定の水深における砕波限界波高と して解析する場合の二つのアプローチがある。構造物の 設計において, その設置位置にある程度の選択が許され れば，砕波帯を避けるようにすることも可能である。し かし, 構造物の設置位置が既定の場合には, その直前に おいて砕波し, 強大な波力をおよぼす波がまず考慮され る。すなおち, 所定の水深における砕波限界の波の検討 が必要になる。

こうした砕波限界波高については, Miche および浜 田が式（3）を示したのを始めとして, 級数表示による 有限振幅波の計算 ${ }^{14)}$ (17), 砕波限界においては波頂が $120^{\circ}$ となる条件をあらかじめ与えて限界波形勾配を計

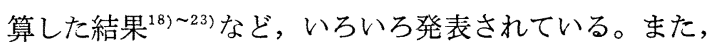
Reid と Bretschneider ${ }^{24)}$ は深海波と孤立波の計算值の
中間を観測值や実験值で補なった半経験的な曲線を示し ており, 著者も先に直柱に働く波力に関連して限界波高 比の実験曲線 ${ }^{25)}$ を提案した。しかしながら，現時点にお いては, 山田・塩谷 ${ }^{23)}$ の計算が最も精度が高いと考えら れるので, その計算結果から工学的に重要と思われる数 值を算出したのが 表一1 である。この表からたとえば, 砕波限界の波の波速は微小振幅波理論による值にくらべ て, 墚海波で $19.3 \%$, 孤立波で $28.5 \%$ 大きく, 浅海 表面波でも $h / L_{0} \fallingdotseq 0.11$ を極小点として約 $13 \%$ 以上の 波長増大率を示すことなどもわかる。

この計算は, 一様水深における䂗波限界を対象とした ものである。一方これと対比すべき実験データとして は, Suquet と Wallet ${ }^{11)}$ の実験があげられるけれども， これはデータ表が付されていないのでくわしい検討がで きない。そこで, 水底勾配 1/100 における著者の実験值 と, 水底勾配 $1 / 50$ のときの Iversen ${ }^{6)}$ および光易 ${ }^{26)}$ の データについて比較したのが 図一1 である。砕波限界 は, $(H / L)_{b}$ と $(h / L)_{b}$ の関係として表示されることが 多いけれども，この表示法では，i） $(h / L)_{b}$ の小さい領

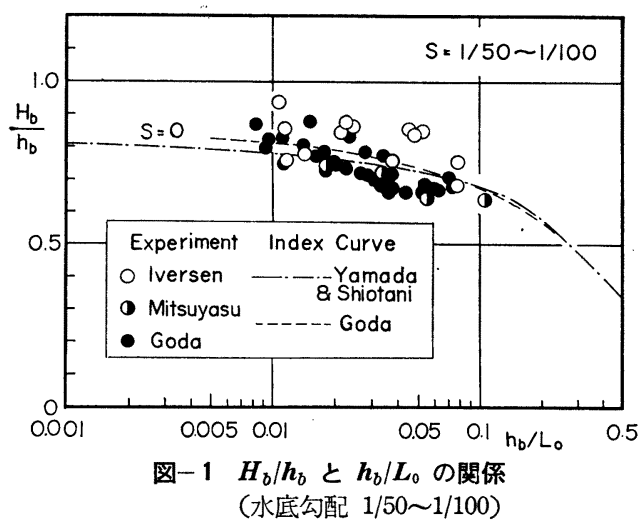

表-1 山田・塩谷 ${ }^{23)}$ による砕波限界の波の特性の計算結果

\begin{tabular}{|c|c|c|c|c|c|c|c|c|c|}
\hline No. & $h_{b} / L_{0}$ & $h_{b} / L_{A}{ }^{*}$ & $h_{b} / L_{b}$ & $C_{b} / C_{A}$ & $H_{b} / L_{0}$ & $H_{b} / L_{b}$ & $H_{b} / h_{b}$ & $\left(\eta_{c} / H\right)_{b}$ & $Y_{b} / h_{b}$ \\
\hline 1 & $\infty$ & $\infty$ & $\infty$ & 1.193 & 0.1684 & 0.1412 & 0 & & 1.0000 \\
\hline 2 & 0.935 & 0.935 & 0.7868 & 1.189 & 0.1675 & 0.1409 & 0.1791 & 0.6706 & 1.1201 \\
\hline 3 & 0.471 & 0.474 & 0.4011 & 1.181 & 0.1629 & 0.1386 & 0.3456 & 0.6765 & 1.2338 \\
\hline 4 & 0.286 & 0.300 & 0.2597 & 1.154 & 0.1407 & 0.1277 & 0.4919 & 0.6908 & 1.3398 \\
\hline 5 & 0.1886 & 0.216 & 0.1885 & 1.143 & 0.1105 & 0.1115 & 0.5912 & 0.7165 & 1.4236 \\
\hline 6 & 0.1117 & 0.1510 & 0.1331 & 1.134 & 0.0746 & 0.08897 & 0.6683 & 0.7619 & 1.5092 \\
\hline 7 & 0.0763 & 0.1198 & 0.1050 & 1.141 & 0.0538 & 0.07410 & 0.7059 & 0.7939 & 1.5604 \\
\hline 8 & 0.0474 & 0.0915 & 0.07915 & 1.156 & 0.0346 & 0.05771 & 0.7293 & 0.8392 & 1.6120 \\
\hline 9 & 0.0284 & 0.0694 & 0.05909 & 1.174 & 0.0213 & 0.04430 & 0.7496 & 0.8766 & 1.6571 \\
\hline 10 & 0.01669 & 0.0525 & 0.04398 & 1.193 & 0.01280 & 0.03371 & 0.7666 & 0.9061 & 1.6946 \\
\hline 11 & 0.01095 & 0.0422 & 0.03499 & 1.207 & 0.00851 & 0.02720 & 0.7774 & 0.9242 & 1.7185 \\
\hline 12 & 0.00575 & 0.0306 & 0.02483 & 1.231 & 0.00454 & 0.01962 & 0.7904 & 0.9453 & 1.7472 \\
\hline 13 & 0.00239 & 0.01953 & 0.01570 & 1.244 & 0.001918 & 0.01260 & 0.8028 & 0.9649 & 1.7746 \\
\hline 14 & 0.001144 & 0.01351 & 0.01075 & 1.257 & 0.000926 & 0.00871 & 0.8099 & 0.9757 & 1.7902 \\
\hline 15 & 0.000437 & 0.00833 & 0.00660 & 1.263 & 0.000357 & 0.00538 & 0.8160 & 0.9849 & 1.8037 \\
\hline 16 & 0 & 0 & 0 & $1.285^{* *}$ & 0 & 0 & $0.8261^{* *}$ & 1.0000 & 1.8261 \\
\hline
\end{tabular}

* $C_{A}, L_{A}$ は微小振幅波としての波速および波長, $C_{A}=\frac{g}{2 \pi} T \tanh \frac{2 \pi h}{L_{A}}, L_{A}=C_{A} T$ である。

** 山田・木村・岡部22)の坬立波の計算に上る。 
域におけるデータの差が十分に表われない，ii）波長 $L_{b}$ を実測あるいは正確に計算することがむずかしく，これ を微小振幅波の波長で代用寸れば前述のように13〜28\% の誤差を生ずる，などの問題を生ずる。そこで，本報告 では 図一1 のように $H_{b} / h_{b}$ と $h_{b} / L_{0}$ の関係として表 示し，検討を行なった。

図一1 を見ると，実験データが平均值から $\pm 15 \%$ の 範囲に散らばっているため厳密な比較はできないが，表 -1 の計算值は実験值とかなり良く一致しているといえ よう。とくに計算值はどちらかといえば実験值の平均よ りもやや低目であり，以下に述べる水底勾配の影響によ って $H_{b} / h_{b}$ が増大寸る傾向をあわせ考えると，表一1 の值は水底勾配 0 のときの砕波限界波高比として十分信 頼できるものと思われる。なお以前に著者が作成した実 験指標 ${ }^{25}$ は，計算值と若干の差があるけれども実用上は ほぼ同一と見なすことができる。

つぎに，水底が傾斜しているときの砕波現象について は，いくつかの理論的研究が行なわれているけれども， 砕波指標の参考になるような計算結果は発表されていな いよらに思われる。そこで, 既往の各種実験報告のうち， 実験条件や実験データが記載されているもの ${ }^{6), 25) ~ 31) ~ に ~}$ ついて，水底勾配別に 図一1 の形に実験值を整理したの が，図一2 4 である。なお，これらの実験の諸元は 表 -2 にまとめて示した。

図一2〜4を見ると実験データの散らばりが大きく， 水底勾配 $1 / 30$ のように Iversen ${ }^{6}$ のデータと豊島ほか29 のデータとで系統的な差が見られる場合や，水底勾配 1/10の Galvin ${ }^{31}$ のデータのように, 同一の実験の中で も大きな差を生じている場合などがあ る。また水底勾配が $1 / 10$ の場合, Iversen は $h_{b} / L_{0}$ がある程度小さくなると $H_{b} / h_{b}$ が減少するような実験曲線を示し ている†。かし他の水底勾配のデータ の傾向や，水底勾配が $1 / 10$ のときの Galvin のデータが $h_{b} / L_{0}$ のさらに小さ い所で大きな $H_{b} / h_{b}$ の値を示している ことなどをあわせ考えると，Iversen の 実験曲線の引き方は砕波限界波高比の一 般的傾向に合致していないと考えられよ う。

このよらに実験データの散らばりなど 問題はあるが，とくに全体からはずれて いるデータを除外して考えれば，各水底 勾配ごとに実験曲線を描くことが可能で

†原論文では $h_{b} / H_{b}$ と $H_{0} / L_{0}$ の関係で示さ れているが,これは $H_{b} / h_{b}$ と $h_{b} / L_{0}$ の関 係に変換することができる。 除外した。
ある。したがって，ほぼ実験值の平均を表わすように， また水底勾配による変化が滑らかに表わせるように考虑 して，実験曲線を 図一2４ の実線のように定めた。

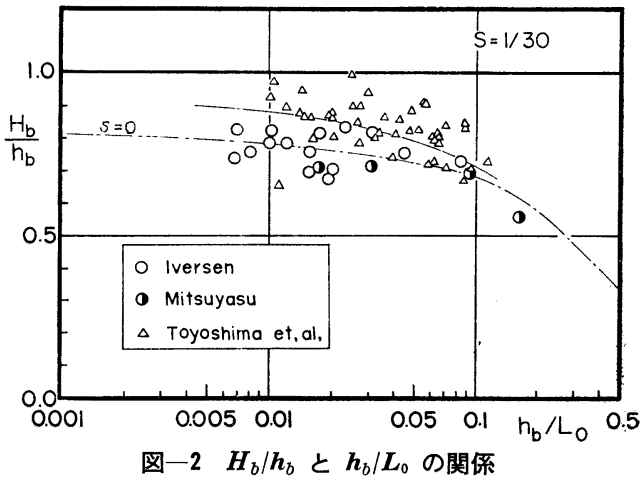

（水底公配 $1 / 30$ )

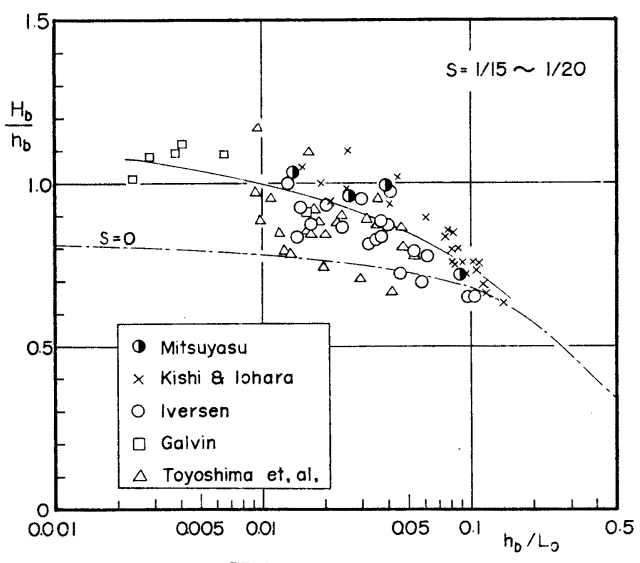

図一3 $\boldsymbol{H}_{b} / \boldsymbol{h}_{b}$ と $\boldsymbol{h}_{b} / \boldsymbol{L}_{0}$ の関係 （水底公配 $1 / 15 \sim 1 / 20$ )

表一2 砕波限界の波に関する実験データの概要

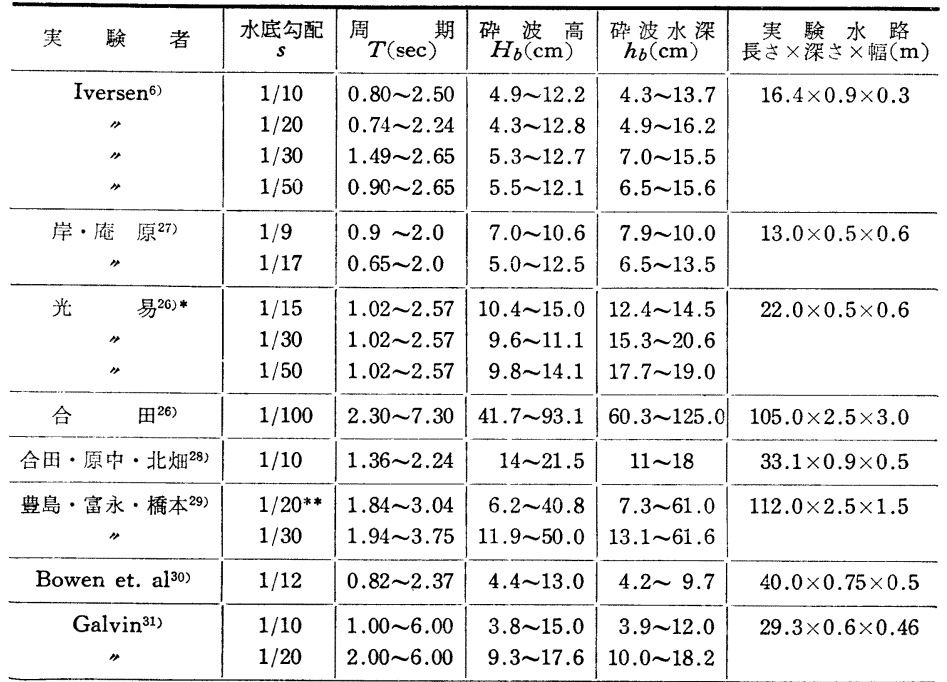

* このデータは, 著者が以前に光易博士の実験ファイルから転記させて頂いたものである。

** この5ち No. 39, 40 のデータは $H_{b} \leq 2.0 \mathrm{~cm}$ であり，また他とか什離れた值を示すので 


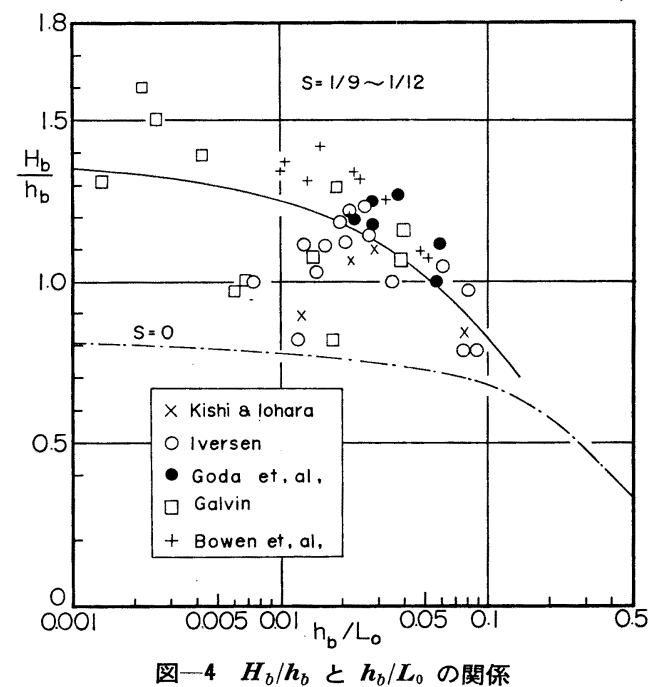

（水底勾配 $1 / 9 \sim 1 / 12$ )

\section{（2）碎波の峯高}

砕波点における波の特性としては, その峯高も重要で ある。これは, 海洋構造物のプラットフォームなどが 波で吒かれないようにするための設計諸元として值接に 必要になる。砕波限界波高比と同じように, 水底勾配別 に実験データをプロットし, 実験曲線を引いたのが 図 -5 8 である。ここで, 縦軸には水底から砕波の波峯 までの高さ $Y_{b}$ と砕波水深 $h_{b}$ との比をとっている。こ

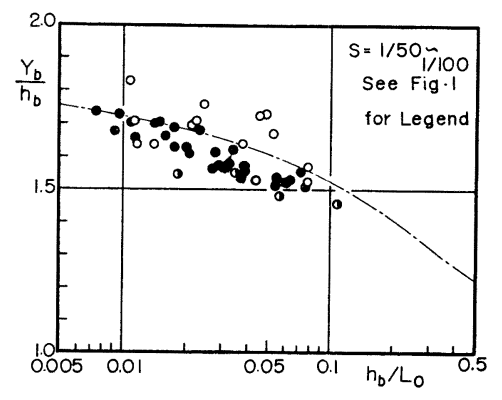

図一5 $\boldsymbol{Y}_{b} / \boldsymbol{h}_{0}$ と $\boldsymbol{h}_{b} \boldsymbol{L}_{0}$ の関係 （水底勾配 1/50 1/100）

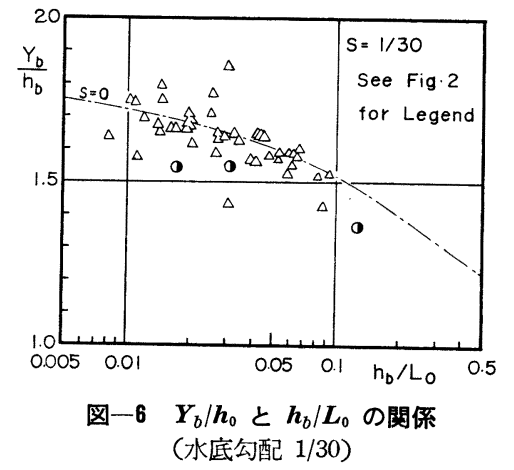

の表示は豊島ほか ${ }^{29}$ が用いたもので，実用上便利な表示 法と思われる。

図一5 8 の実験曲線の らち，水底勾配 1/50 1/100 および 1/30 のものは, 表一1 に示した山田・塩谷の計 算值であり，実験データはこの計算值の上下にほぼ平均 して散らばっている。すでに 図一1〜4において水底の 傾斜によって $H_{b} / h_{b}$ が増大する傾向が表われているの であるから， $Y_{b} / h_{b}$ の值が $s=1 / 30$ 以下では変化しない ことは, 波の山の部分の相対的割合 $\left(\eta_{c} / H\right)_{b}$ が水底 の傾斜とともに減少することを意味している。実際に $\left(\eta_{c} / H\right)_{b}$ と $h_{b} / L_{0}$ との関係を実験データについて調べ てみると，この傾向が表われており，水底勾配 $1 / 10$ な ぞでは $\left(\eta_{c} / H_{b}\right)$ の平均值が 0.75 程度にしかならない。 なお，図一7および図一8 の実験曲線は，あらかじめ実 験データについて $\left(\eta_{c} / H\right)_{b}$ と $h_{b} / L_{0}$ との関倸を求め, これと $H_{b} / h_{b}$ と $h_{b} / L_{0}$ の関係を組み合わせて求めたも のである。

\section{（3）限界設計波高}

研波を設計の対象とする場合，もら一つ考えなければ ならない問題は, 最大の波力を生ずるのは構造物の設置 地点でちようど砕ける波よりも, むしろそのやや前方で 砕け始める波である ${ }^{26), 28)}$ ことである。すなわち，水深 としてやや深い所の研波が対象となるから, 砕波高とし

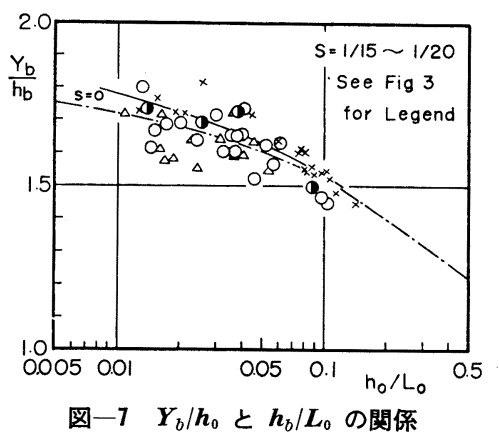

(水底勾配 $1 / 15 \sim 1 / 20$ )

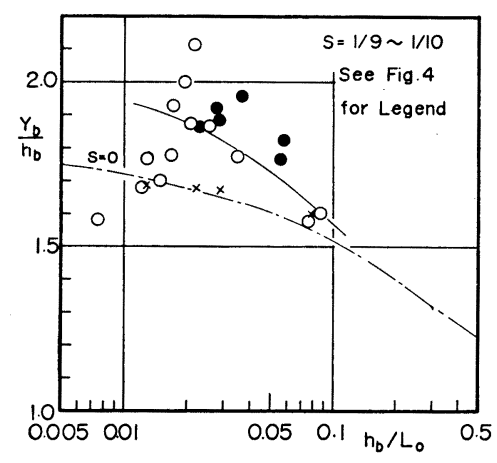

図-8 $\boldsymbol{Y}_{b} / \boldsymbol{h}_{0}$ と $\boldsymbol{h}_{b} / \boldsymbol{L}_{0}$ の関係 （水底勾配 1/9 1/10） 
てもやや大きなものを考慮しなければならない。図一1 ４に示した砕波限界は, 実験者によって若干の差異は あるが，ほぼ波が砕け始める初期砕波点に関するもので ある。したがって，設計波の選定の際に構造物の設置水 深を $h_{b}$ として 図一1〜4 省用いたのでは，波高を過小 に見積ることになる。Galvin ${ }^{31}$ はこうした観点から， 巻き波が砕け始めてからその先端が水面に落下するまで にどのくらいの距離を進行するかを実験的に調べ，水底 勾配が 1/5〜1/20 ではこの距離が (1.5〜4.9) $H_{b}$ 程度 であり，水底勾配が急なときは距離がやや短くなること を示している。

いま，水深 $h$ の地点に設置された構造物に対して， 最大の波力をおよぼすような波の波高を限界設計波高 $H_{B M}$ と仮称 ${ }^{32)}$ し,$H_{B M} / h$ と $h / L_{0}$ との関係を調べる と図一9のようになる。このような解析を行ない得る データは, 鉛直壁に働く波力に関する光易 ${ }^{26)}$ の実験值, および直柱に働く砕波力に関する $\mathrm{Hall}^{33)}$ ならびに著 者 ${ }^{28}$ の実験值で，数が少ないために，限界設計波高の概

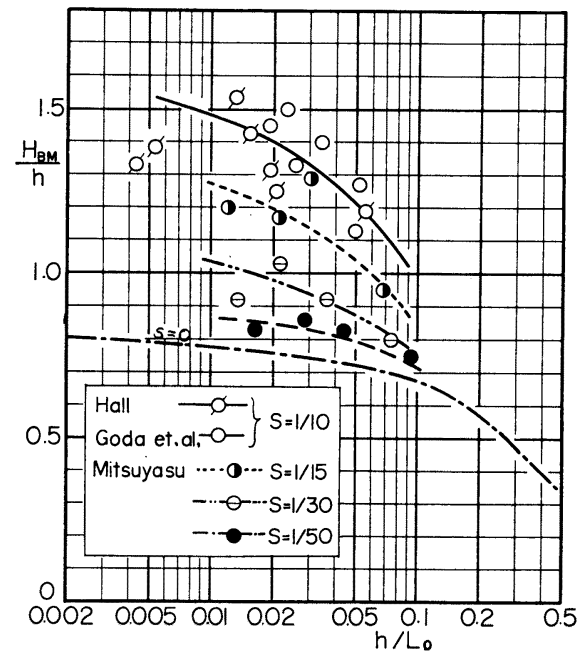

図一9 限界設計波高 $H_{B M}$ の概略值
略值を示すにとどまる。しかし，図-1４ とくらべて みるとわかるよ らに，H/h の值にして，水底勾配 $1 / 10$ で $0.15 \sim 0.25$ ，水底勾配 $1 / 30$ で $0.06 \sim 0.15$ ，水底勾 配 1/50 で 0.05 0.10 积度増大している。したがって, 水底勾配が急な場合は，とくにこうした砕波点と最大波 力を生ずる点の差を考えることが重要になる。

\section{3. 沖波の諸元と砕波諸元との関係}

\section{（1） 水深変化による波高変化の理論值}

つぎに, 沖波の波高 $H_{0}$ および周期 $T$ から砕波水深 $h_{b}$ と砕波高 $H_{b}$ を推定する問題の場合，いままでは主 に観測あるいは実験值の平均曲線として砕波指標が求め られてきた。しかし，波が深海から浅海へ進んだときの 波高変化は理論的に計算されているので，砕波指標の決 定にあたっては，こうした波高の理論值を考慮に入れる のが至当である。

まず第 1 次近似としての微小振幅波の理論では, 波高 の変化がつぎのように表わされる。

$$
\frac{H}{H_{0}}=K_{s}=\sqrt{\frac{2 \cosh ^{2} 2 \pi h / L}{4 \pi h / L+\sinh 4 \pi h / L}} \cdots
$$

しかし, 実際には有限振幅の影響で波高変化率は式 (4) による值よりやや大きくなり, とくに砕波点のように波 形勾配が大きい場合には，この差が無視できなくなる。 このような有限振幅の波の波高変化については, LeMéhauté と Webb ${ }^{34)}$ および Koh と LeMéhautéét ${ }^{35)}$ がス トークス波について計算を行ない，岩垣 ${ }^{36), 37)}$ はクノイ ド波理論の初等関数表示であるハイパボリック波につい て計算している。そこで，この計算結果を示した図表 ${ }^{36)}$ で砕波限界と記されている曲線から波高変化率その他を 読み取ると，表一3 のようになる。ただし図表から読み 取りのため若干の䛊差は生じていよう。

このうち，ストークス波の砕波限界としてどのような

表一3 有限振幅波の shoaling の計算結果 ${ }^{86}$

\begin{tabular}{|c|c|c|c|c|c|c|c|c|c|c|}
\hline \multirow{2}{*}{$H_{0} / L_{0}$} & \multicolumn{2}{|r|}{ 計 } & 算 & \multicolumn{2}{|l|}{ 値 } & \multicolumn{4}{|c|}{ 修 正 值 $(s=1 / 50$ 以下 $)$} & \multirow{2}{*}{ 備 } \\
\hline & $H_{b} / H_{0}$ & $H_{b} / L_{0}$ & $h_{b} / L_{0}$ & $h_{b} / H_{0}$ & $H_{b} / h_{b}$ & $h_{b} / L_{0}$ & $h_{b} / H_{0}$ & $H_{b} / h_{b}$ & $H_{b} / H_{0}$ & \\
\hline 0.12 & 0.945 & 0.113 & 0.19 & 1.58 & 0.60 & 0.195 & 1.62 & 0.57 & 0.94 & \\
\hline 0.10 & 0.950 & 0.095 & 0.14 & 1.40 & 0.68 & 0.150 & 1.50 & 0.63 & 0.94 & \\
\hline 0.08 & 0.975 & 0.078 & 0.11 & 1.37 & 0.71 & 0.118 & 1.48 & 0.66 & 0.98 & ストークス波 \\
\hline 0.06 & 1.006 & 0.061 & 0.084 & 1.38 & 0.72 & 0.088 & 1.47 & 0.69 & 1.01 & \\
\hline 0.04 & 1.056 & 0.042 & 0.060 & 1.51 & 0.70 & 0.059 & 1.47 & 0.71 & 1.05 & \\
\hline 0.020 & 1.24 & 0.0248 & 0.040 & 2.00 & 0.62 & 0.033 & 1.65 & 0.74 & 1.22 & \\
\hline 0.015 & 1.33 & 0.0200 & 0.0315 & 2.09 & 0.64 & 0.026 & 1.73 & 0.75 & 1.30 & \\
\hline 0.010 & 1.46 & 0.0146 & 0.023 & 2.30 & 0.64 & 0.019 & 1.90 & 0.76 & 1.45 & \\
\hline 0.008 & 1.54 & 0.0123 & 0.0195 & 2.44 & 0.63 & 0.016 & 2.00 & 0.77 & 1.54 & \\
\hline 0.006 & 1.66 & 0.0100 & 0.016 & 2.67 & 0.62 & 0.0129 & 2.15 & 0.77 & 1.66 & ハ1ハホリッグ波 \\
\hline 0.004 & 1.86 & 0.0074 & 0.0115 & 2.88 & 0.64 & 0.0095 & 2.38 & 0.78 & 1.85 & \\
\hline 0.003 & 2.01 & 0.0060 & 0.0091 & 3.05 & 0.65 & 0.0077 & 2.57 & 0.78 & 2.01 & \\
\hline 0.002 & 2.25 & 0.0045 & 0.0066 & 3.30 & 0.68 & 0.0057 & 2.85 & 0.79 & 2.26 & \\
\hline
\end{tabular}


指標が用いられたかは明示されていないが，結果から判 断すると式 (3) に近いもののよ5である。一方, ハイ パボリック波の計算では, 基礎式に用いた Laitone $\mathrm{e}^{38)}$ の 理論における砕波限界が $(H / h)_{\max }=0.73$ であるとこ ろから， $h / L \rightarrow 0$ でこれに収束するような砕波指標が用 いられている。したがって, 表一3 の $H_{b} / h_{b}$ の計算值 の闌に見らるように, ストークス波の下限である $H_{0} / L_{0}$ $=0.04$ からハイパボリック波の上限である $H_{0} / L_{0}=0.02$ に移るところで, $H_{b} / h_{b}$ の值が急に減少している。実際 には 表一1 の計算に示されているように $H_{b} / h_{b}$ の変化 は連続であるから，ハイパボリック波の計算值について は $H_{b} / H_{0}$ および $h_{b} / H_{0}$ の両者あるいはそのいずれか についての修正が必要と考えられる(この修正について は(3) で述べる)。

\section{（2）実験データに対する波高減衰の補正}

以上の波高変化の理論值を実験值と比較し, 硴波指標 を作成する作業を進めるためには，まず実験データを吟 味しておく必要がある。すでに Iversen の実験(6),7) で も, 波が水路内を進行するにつれて波高が減衰すること が示されており, Iversen 自身もこの補正方法について 検討している。しかし彼の試みた方法は, あらかじめ沖 波波高と減衰の影響を受けた水路内の波高との関係を実 験的に求めておき, 一様水深部における波高の測定值か ら減衰する前の沖波波高を推定するやり方であり, 結局 はこうした補正を行なわない場合の実験曲線を採用し た。

しかし, Iversen の試みた方法は, 補正のしかたが逆 であった。すなわち, 補正が必要なのは沖側の波高測定 点から研波点に波が進行する間の減衰であり, これによ って相当沖波波高がどの程度に減少したかを見積ること が必要である。いま, 実験の手法を考えてみると, 斜面 の先端から沖側の一様水深部で波高 $H_{1}$ を測定し, これ から沖波波高 $H_{0}$ を式（4）に基づいて

$$
H_{0}=H_{1} /\left(K_{s}\right)_{1} \cdots
$$

で推定するのが普通である。ただし， $\left(K_{s}\right)_{1}$ は一様水深 部の水深 $h_{1}$ に対する浅水係数である。この波が水深 $h_{2}$ の地点にまで進んだとき, もし底面および側面の摩擦に よる減衰の影響がなければ, 波高 $H_{2}$ は水深 $h_{2}$ に対す る浅水係数を $\left(K_{s}\right)_{2}$ としてつぎのようになる。

$$
H_{2}=\left(K_{s}\right)_{2} \times H_{0} \cdots
$$

しかし, 実際には摩擦による減衰作用が働いているか ら，これによる波高の減少率を $K_{f}$ として，水深 $h_{2}$ に おける波高はつぎのようになる。

$$
\begin{aligned}
& H_{2}{ }^{\prime}=K_{f} \times\left(K_{s}\right)_{2} \times H_{0}=\left(K_{s}\right)_{2} \times H_{0}{ }^{\prime} \\
& \text { ここ}, \\
& H_{0}{ }^{\prime}=K_{f} \times H_{0} \ldots \ldots \ldots \ldots \ldots \ldots \ldots \ldots \ldots \ldots \ldots \ldots \ldots \ldots \ldots \ldots \ldots \ldots \ldots \ldots
\end{aligned}
$$

すなわち, 水深 $h_{2}$ の地点に対する沖波波高は，水深 $h_{1}$ の地点の測定波高から式 ( 5 ) で推定した $H_{0}$ そのまま ではなくて,これに水路内の摩擦作用によって減少した 割合 $K_{f}$ を乗じた式 $(8)$ の $H_{0}{ }^{\prime}$ である。

この補正計算に扔いて重要なのは, 波高減少率 $K_{f}$ の 算定である。岩垣ほか ${ }^{39}$ の研究によると, 水深 $h$, 幅 $B$ の水路を距離 $x$ だけ進行したときの波高減少率の理論 值はつぎのように表わされる。

$$
\begin{aligned}
& K_{f}=\frac{H_{2}}{H_{1}}=\exp \left[-\epsilon_{b+w} x / L\right] \\
& \text { ここに, } \\
& \epsilon_{b+w}=\frac{4 \pi^{2}}{L} \sqrt{\frac{\nu T}{\pi}}\left(1+\frac{1}{\Psi}\right) \cdot \frac{1}{k h+\sinh k h} \\
& \Psi=\frac{k B}{\sinh 2 k h} \cdot\{1-(1.086 \operatorname{sech} k h+0.197) \varepsilon\} \\
& \varepsilon=\frac{\pi H}{L} \cdot \frac{1}{\sinh k h}, \quad k=\frac{2 \pi}{L} \\
& \nu: \text { 水の動粘性係数 }
\end{aligned}
$$

ただし, 実験の結果は平均して式 (9) による值よりも 減衰が著しく, $\epsilon_{b}$ の值にして 20 30\% 大きいと報告さ れている。したがって，本報告では

$$
\epsilon_{b+w^{\prime}}=1.25 \epsilon_{b+w} \cdots
$$

として波高減少率を計算することにした。

この補正計算を砕波データについて行なら場合は水深 が変化するので, 沖側の測定点から砕波点までをいくつ かの区間に分割して式 (9) を適用することが必要にな る。本報告では，水底があらかじめ定めた高さ $\Delta h$ だけ 上昇する所で区間を切り，全体として 20〜30 区間にな るように $\Delta h$ を与えた。また， $\varepsilon$ で表示されている波形 勾配の影響については, 有限振幅波としての波高を求め るのが大変なので, 式 (4) の浅水係数を用いて計算し た。表一2 にあげた実験データのらち, 波高減衰の補正 計算を行なったものについてその諸元を記すと, 表一4 のようになる。ただし一様水深部の波高測定位置など報 告に明記されていないものについては, 水路の大きさや 斜面先端の位置などから判断した想定值を用いた。

表一4の結果では, Iversen の実験が水路幅が狭いた めもあって波高減衰の影響が最も大きく, 波高が最大約 $13 \%$ 減少したものと推定される。また, 大型水路を使 用した豊島ほかの実験でも, 比較的短周期の波を使った ためか最大約 $6 \%$ の波高减少があったものと推定され る。

本章でデータとして用いた実験值は，すべてこの波高 減衰の補正計算を行ない, 沖波波高として式 (8) の值 を用いた。また, $H_{1}$ から $H_{0}$ を求める際, 厳密には有 限振幅の影響を考慮すべきであるが，これは計算が大変 であり,また今後の実験データとの比較の便宜も考え 
表一4 波高滅衰率の計算諸元

\begin{tabular}{|c|c|c|c|c|c|c|}
\hline \multirow{2}{*}{ 実 } & \multirow{2}{*}{ 験 } & \multirow{2}{*}{$\begin{array}{c}\text { 水底勾配 } \\
s\end{array}$} & \multicolumn{2}{|c|}{ 沖 波 測 定 点 } & \multirow{2}{*}{$\begin{array}{l}\text { 厁面点 } \\
\text { 離 } \\
x_{2}(\mathrm{~m})\end{array}$} & \multirow{2}{*}{$\begin{array}{c}\text { 波 高 減衰率 } K_{f} \\
\text { 最小値～最大值（平均値 }\end{array}$} \\
\hline & & & $h_{1}(\mathrm{~cm})$ & $x_{1}(\mathrm{~m})^{*}$ & & \\
\hline \multicolumn{2}{|c|}{ Iversen } & $1 / 10$ & $65.5 \sim 70.1$ & $(3.0)$ & $5.7 \sim 6.4$ & $0.888 \sim 0.970(0.941)$ \\
\hline & & 44.8 & ( & $6.8 \sim 8.2$ & $0.958(0.929)$ \\
\hline \multicolumn{2}{|r|}{ " } & 30 & $42.7 \sim 50.3$ & (1. & $10.4 \sim 11.1$ & $0.897 \sim 0.950(0.933)$ \\
\hline \multicolumn{2}{|r|}{ " } & $1 / 50$ & 46.9 & $(0.6)$ & $4.8 \sim 9.3$ & $0.898 \sim 0.976(0.936)$ \\
\hline \multirow[t]{3}{*}{ 光 } & \multirow[b]{2}{*}{$"$} & $1 / 15$ & 35.0 & & $.1 \sim 3.4$ & $-0.985(0.982)$ \\
\hline & & $1 / 30$ & $"$ & 0.0 & $7.3 \sim 8.9$ & $0.967 \sim 0.981 \quad(0.975)$ \\
\hline & $"$ & $1 / 50$ & " & 0.0 & $8.0 \sim 8.8$ & $0.944 \sim 0.970(0.959)$ \\
\hline 合 & 田 & $1 / 100$ & $100.0,150.0$ & 5.7 & $21.8 \sim 37.0$ & $0.979 \sim 0.995(0.988)$ \\
\hline \multirow{2}{*}{\multicolumn{2}{|c|}{$\begin{array}{c}\text { 豊島・富永・橋本 } \\
\text { " }\end{array}$}} & $1 / 20$ & $100.0 \sim 150.0$ & $(33.0)$ & $(18.0 \sim 20.0)$ & $0.937 \sim 0.975(0.956)$ \\
\hline & & $1 / 30$ & " & $(18.0)$ & $(18.0 \sim 20.0)$ & $0.947 \sim 0.975(0.966)$ \\
\hline \multicolumn{2}{|c|}{ Bowen et. al. } & $1 / 12$ & $(60.0)$ & $(5.0)$ & $(6.1 \sim 6.8)$ & $0.893 \sim 0.965(0.939)$ \\
\hline
\end{tabular}

* 斜面先端から沖波測定点までの距離。

** カッコでくくったものは，数值が明示されていないため著者か想定した值である。
く,また $H_{0} / L_{0}$ の小さい所では 表一3 の計算値よりもかなり低い 值を示す。したがって，(1)の 最後で述べた $H_{b} / h_{b}$ の不連続性 の修正としては, $h_{b} / H_{0}$ について 行ならのが適当と考えられる。た だし, 実験データから直接 $h_{b} / H_{b}$ と $H_{b} / L_{0}$ との関係曲線を描くの は, データの散らばりのために不 正確になる。そこで，まず $h_{b} / L_{0}$ と $H_{0} / L_{0}$ との関係を求め, この 結果から $h_{b} / H_{0}$ の実験曲線を決 定することにした。

ところで, $h_{b} / L_{0}$ と $H_{0} / L_{0}$ の
て，一応微小振幅波としての浅水係数を用いることにし た。

\section{（3）碎波高および碎波水深の実験曲線の決定}

沖波の諸元と确波諸元との関係を調べる場合，（1） で述べた理論計算の結果が一つの基準となるけれども, その前にこれを実験值とくらべてみることが必要であ る。理論計算はもともと水底の傾斜が非常に緩やかな状 態を対象しているから，実験值としても水底勾配が最も 緩やかな $1 / 100$ および $1 / 50$ のデータとくらべるのが妥 当である。そこで, $H_{b} / H_{0}$ と $H_{0} / L_{0}$ との関係について 実験值と計算值を比較したのが 図一10 である。これを 見ると, Iversen のデータに計算值をかなり下まわるも のがいくつかあることを除けば，実験值は計算值と良く 一致しているといえる。また，Iversen の実験指標は実 験データの平均值より低く，ほぼ下限值に近い。したが って, 以後の作業においては表一3 の計算值のうち $H_{b} / H_{0}$ と $H_{0} / L_{0}$ の関係を基準值に用いることにした。

つぎの砕波水深について $h_{b} / H_{0}$ と $H_{0} / L_{0}$ との関倸を 実験值について調べてみると, データの散らばりが大き

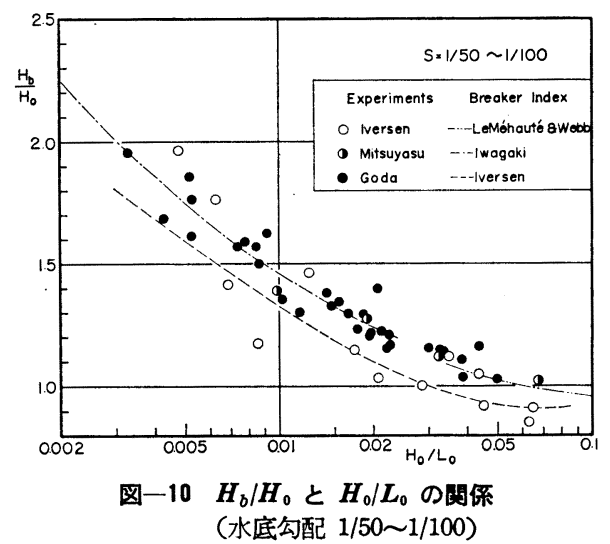

関倸は, 表一1 と表一3 の計算結果を用いて求めること が可能である。すなわち, 山田・塩谷 ${ }^{23)}$ の計算では沖波 波高との関係は求められていないけれども, $H_{b} / L_{0}$ と $h_{b} / L_{0}$ の関係は与えられている。一方, 岩垣と酒井 ${ }^{36}$ の 計算值のうち $H_{b} / H_{0}$ と $H_{0} / L_{0}$ の関係は 図一10 のよ らに実験的に検証されている。したがって,これを $H_{b}$ $L_{0}$ と $H_{0} / L_{0}$ の関係に書き改め, 山田と塩谷の計算值と 比較すれば, $h_{b} / L_{0}$ と $H_{b} / L_{0}$ の関係が求められる。こ うして計算した結果を水底勾配が 1/50 1/100の実験值 と比較したのが図一11 であり, 実験值との一致は良好で ある。そこで, この $h_{b} / L_{0}$ と $H_{0} / L_{0}$ の関倸から $h_{b} / H_{0}$ の值を計算し, 実験值と比較したのが 図一12 である。 なお, この修正計算の結果は 表一3 修正值の各欄に示 してある。実験值の散らばりが大きいため,はっきりは いえないが, 計算值は実験值のほぼ平均的な值を与えて いるといえよう。また, Iversen の実験指標はこの場合 の自分のデータには則しているが, 他のデータの傾向と は一致していない。

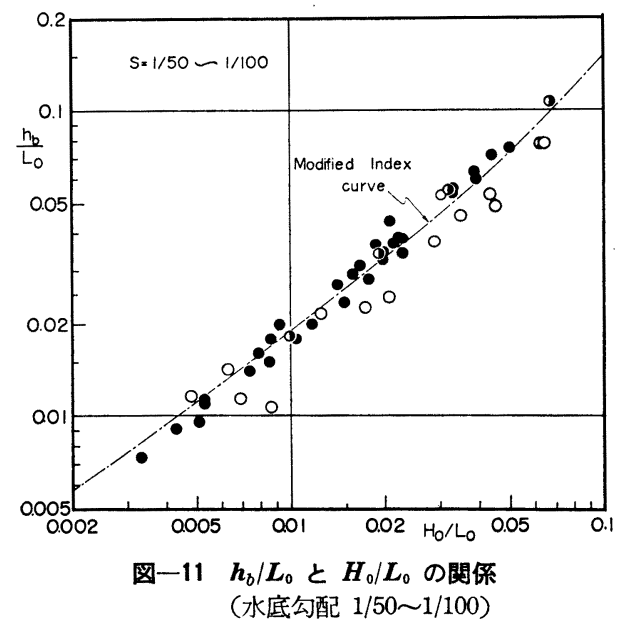


同様にして水底勾配が $1 / 30 ， 1 / 20 ＼mathrm{~ お よ ひ ゙ ~} 1 / 10$ につ いて $h_{b} / L_{0}$ の実験值を $H_{0} / L_{0}$ に対してプロットし, 図 -11 の計算値を参考にして実験曲線を定め, これを $h_{b} / H_{0}$ と $H_{0} / L_{0}$ の関係に換算して実験值と比較したの が図一13〜15 である。また, 図一2 4 の $H_{b} / h_{b}$ と $h_{b} / L_{0}$ の実験曲線と組み合せて $H_{b} / H_{0}$ と $H_{0} / L_{0}$ の関 係を算定し，実験值と比較したのが 図一16〜18 である。

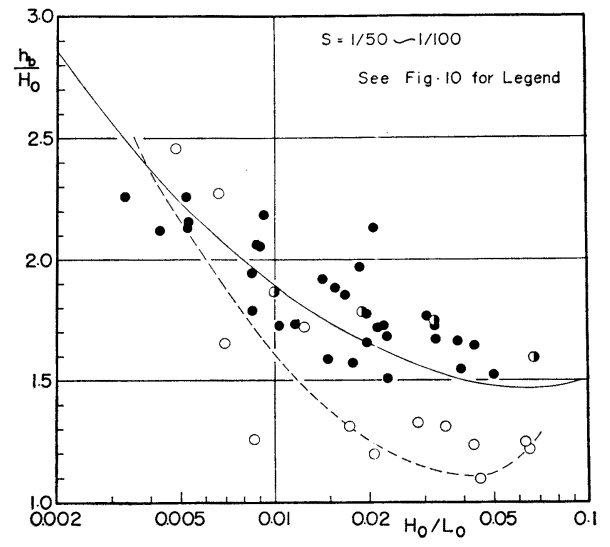

図一12 $h_{b} / H_{0}$ と $H_{0} / L_{0}$ の関係 （水底勾配 1/50 1/100）

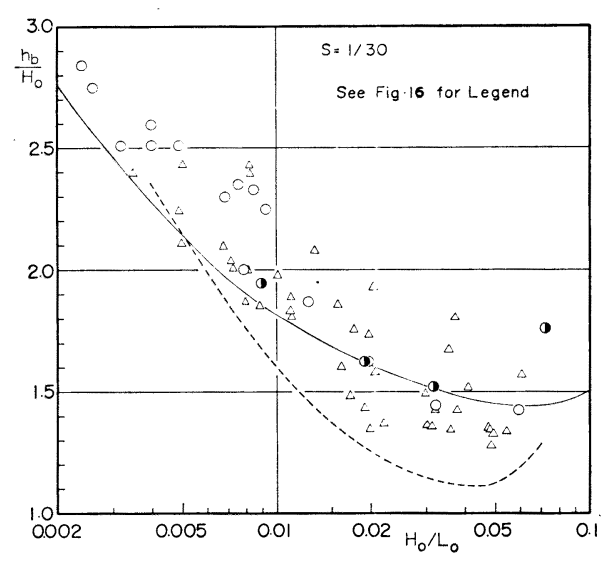

図-13 $h_{b} / H_{0}$ と $H_{0} / L_{0}$ の関係 （水底勾配 $1 / 30$ )

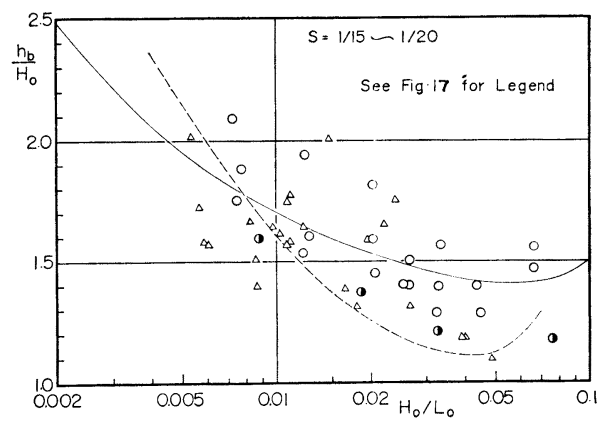

図一14 $h_{b} / H_{0}$ と $H_{0} / L_{0}$ の関係 （水底勾配 $1 / 15 \sim 1 / 20$ ）

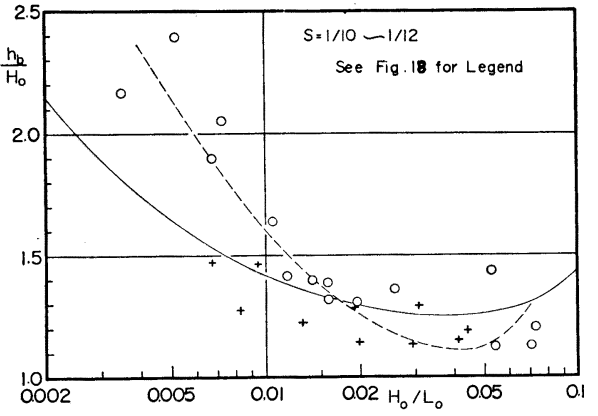

図- $15 h_{b} / H_{0}$ と $H_{0} / L_{0}$ の関係 (水底勾配 $1 / 10 \sim 1 / 12$ )

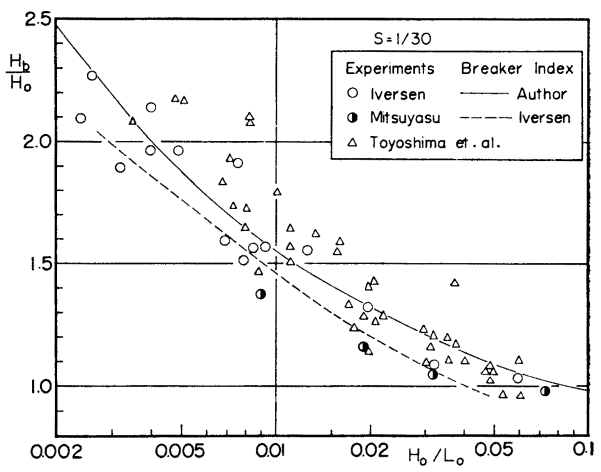

図一16 $H_{b} / H_{0}$ と $H_{0} / L_{0}$ の関係 (水底勾配 1/30)

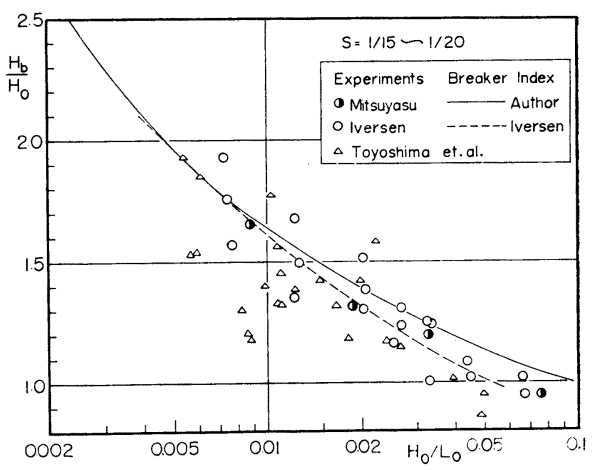

図-17 $\boldsymbol{H}_{b} / \boldsymbol{H}_{0}$ と $\boldsymbol{H}_{0} / \boldsymbol{L}_{0}$ の関係 (水底勾配 $1 / 15 \sim 1 / 20$ )

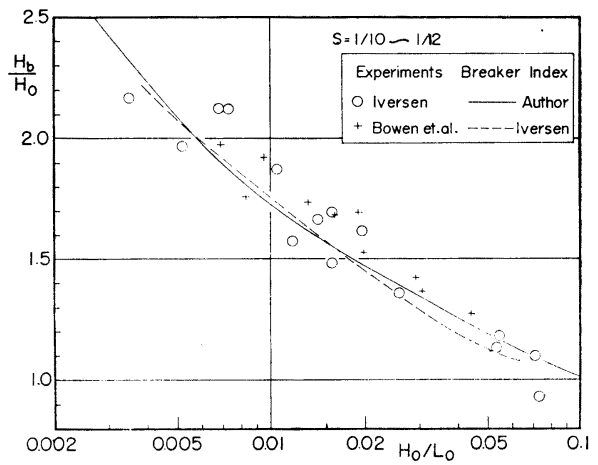

図一18 $\boldsymbol{H}_{b} / \boldsymbol{H}_{0}$ と $\boldsymbol{H}_{0} / \boldsymbol{L}_{0}$ の関係（水底勾配 $\left.1 / 10 \sim 1 / 12\right)$ 
表一5 水底勾眍 $1 / 10 \sim 1 / 30$ に対する砕波指標の算定結果

\begin{tabular}{|c|c|c|c|c|c|c|c|c|c|c|c|c|}
\hline \multirow{2}{*}{$H_{0} / L_{0}$} & \multicolumn{4}{|c|}{ 水底 勾配 $1 / 30$} & \multicolumn{4}{|c|}{ 水底 勾 $1 / 20$} & \multicolumn{4}{|c|}{ 水底 勾配 $1 / 10$} \\
\hline & $h_{b} / L_{0}$ & $h_{b} / H_{0}$ & $H_{b} / h_{b}$ & $H_{b} / H_{0}$ & $h_{b} / L_{0}$ & $h_{b} / H_{0}$ & $H_{b} / h_{b}$ & $H_{b} / H_{0}$ & $h_{b} / L_{0}$ & $h_{b} / H_{0}$ & $H_{b} / h_{b}$ & $H_{b} / H_{0}$ \\
\hline 0.12 & 0.195 & 1.62 & 0.58 & 0.94 & 0.195 & 1.62 & 0.59 & 0.95 & 0.195 & 1.62 & 0.60 & 0.98 \\
\hline 0.10 & 0.150 & 1.50 & 0.64 & 0.96 & 0.150 & 1.50 & 0.65 & 0.97 & 0.145 & 1.45 & 0.70 & 0.98 \\
\hline 0.08 & 0.117 & 1.46 & 0.68 & 1.00 & 0.114 & 1.42 & 0.72 & 1.02 & 0.108 & 1.35 & 0.79 & 1.07 \\
\hline 0.06 & 0.086 & 1.43 & 0.73 & 1.05 & 0.084 & 1.40 & 0.77 & 1.09 & 0.077 & 1.28 & 0.90 & 1.15 \\
\hline 0.04 & 0.059 & 1.47 & 0.77 & 1.14 & 0.057 & 1.42 & 0.83 & 1.18 & 0.050 & 1.25 & 1.01 & 1.26 \\
\hline 0.03 & 0.045 & 1.51 & 0.80 & 1.21 & 0.044 & 1.46 & 0.86 & 1.26 & 0.038 & 1.26 & 1.07 & 1.35 \\
\hline 0.02 & 0.032 & 1.60 & 0.82 & 1.32 & 0.031 & 1.55 & 0.90 & 1.39 & 0.026 & 1.30 & 1.14 & 1.48 \\
\hline 0.015 & 0.025 & 1.68 & 0.84 & 1.41 & 0.024 & 1.63 & 0.92 & 1.50 & 0.020 & 1.33 & 1.18 & 1.58 \\
\hline 0.010 & 0.0182 & 1.82 & 0.85 & 1.55 & 0.0172 & 1.72 & 0.96 & 1.64 & 0.0141 & 1.41 & 1.21 & 1.71 \\
\hline 0.008 & 0.0152 & 1.90 & 0.86 & 1.64 & 0.0142 & 1.78 & 0.97 & 1.72 & 0.0119 & 1.49 & 1.23 & 1.84 \\
\hline 0.006 & 0.0123 & 2.05 & 0.87 & 1.79 & 0.0113 & 1.88 & 0.99 & 1.86 & 0.0095 & 1.58 & 1.25 & 1.98 \\
\hline 0.004 & 0.0091 & 2.27 & 0.88 & 2.00 & 0.0083 & 2.08 & 1.01 & 2.10 & 0.0070 & 1.75 & 1.27 & 2.23 \\
\hline 0.003 & 0.0074 & 2.47 & 0.89 & 2.19 & 0.0067 & 2.23 & 1.03 & 2.29 & 0.0057 & 1.90 & 1.29 & 2.44 \\
\hline 0.002 & 0.0055 & 2.75 & 0.89 & 2.46 & 0.0051 & 2.55 & 1.04 & 2.65 & 0.0043 & 2.15 & 1.30 & 2.80 \\
\hline
\end{tabular}

なおこの算定結果は 表一5 に一括して示した。

まず，砕波水深について $h_{b} / H_{0}$ と $H_{0} / L_{0}$ の関係を 図一13〜15 に見ると, 実験值の散らばりが大きいけれ ども，算定曲線はほぼ実験值の平均を示しているといえ よう。もっとも, 水底勾配 $1 / 10$ の場合の Iversen のデ 一タのうち $H_{0} / L_{0}<0.01$ の 4 点が算定曲線からはずれ て非常に大きな值を示しているけれども，これは 図一4 で $H_{b} / h_{b}$ が他のデータよりも低い值を示していること に対応しており，実験波の状況など他と異なるものがあ ったのではないかと思われる。また, Iversen は $h_{b} /$ $H_{0}$ が水底勾配に関係しないとして単一の実験指標を与 えているけれども, 図一13,14に見られるよ5に自分 自身のデータからもはずれている。実験データは水底勾 配が急になるにつれて $h_{b} / H_{0}$ が減少する傾向を示して おり，表一5 の算定結果とあわせ考えると， $h_{b} / H_{0}$ の指 標も水底勾配によって変化するといらことができる。

一方, 砕波高について $H_{b} / H_{0}$ と $H_{0} / L_{0}$ の関係を示 す図一16〜18 を調べると, やはり実験データの散らば りが大きいけれども，今回求めた算定曲線はほぼ妥当な 指標を与えているといえよう。また, Iversen の実験指 標は水底勾配が急になると今回の算定曲線とほとんど差 がなくなる。

\section{4. 新砕波指標の算定図表}

以上の図中に示した実験および算定曲線をまとめて砕 波指標の算定図表としたのが 図一19 22 である。図一 19, 20 は砕波点における波の特性として $H_{b} / h_{b}$ および $Y_{b} / h_{b}$ と $h_{b} / L_{0}$ の関係, 図一21, 22 は沖波との関係を 表わすものとして, $h_{b} / H_{0}{ }^{\prime}$ および $H_{b} / H_{0}{ }^{\prime}$ と $H_{0}{ }^{\prime} / L_{0}$ の関係をそれぞれ示す。ただし， $H_{0}{ }^{\prime}$ は屈折の影響を考 えた相当沖波波高で $H_{0}{ }^{\prime}=K_{r} \cdot H_{0}$ である（Kr は屈折 係数)。なお，これらの算定図表は，表一1, 3, 5 の計算

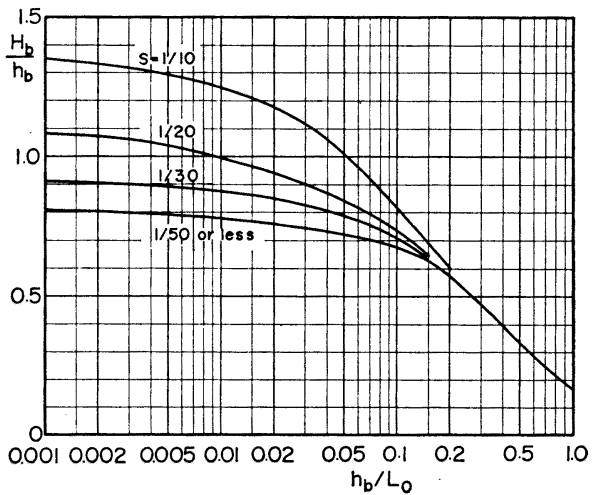

図一19 $H_{b} / h_{b}$ の算定図表

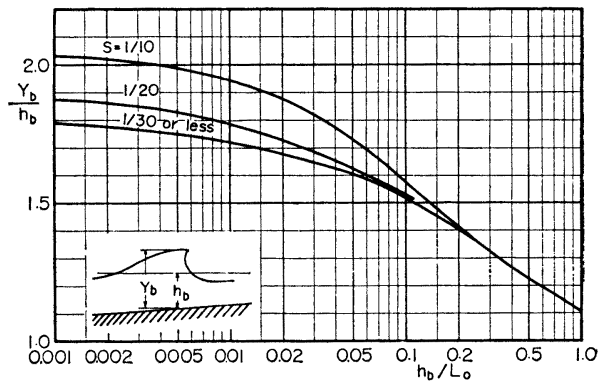

図一20 $\boldsymbol{Y}_{b} / \boldsymbol{h}_{b}$ の算定図表

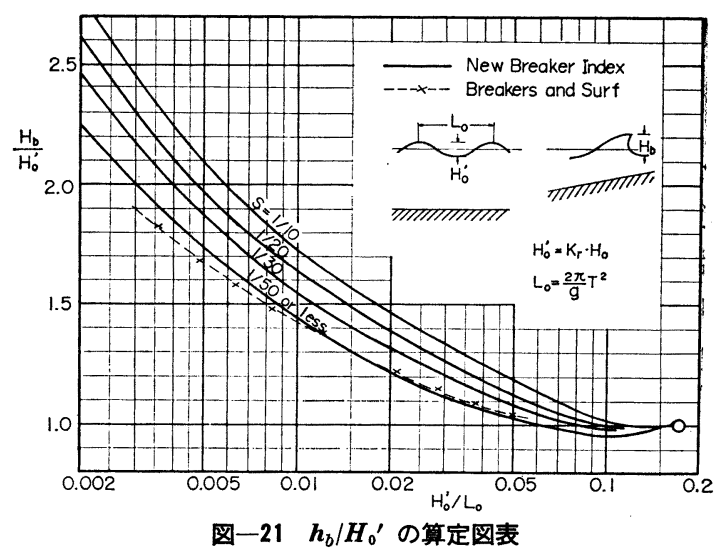




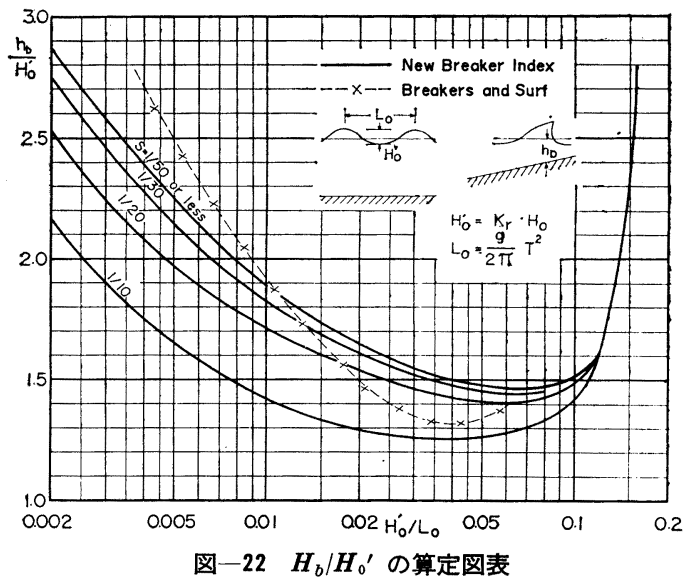

結果を用いて実験データのない部分にまで拡張してあ る。また図一21，22には，比較のため旧砕波指標 (Breakers and surf $)^{1)}$ も併示した。このうち $H_{b} / H_{0}^{\prime}$ の指 標水水底勾配 $1 / 50$ 以下の今回の指標とほとんど一致し ているが, $h_{b} / H_{0}{ }^{\prime}$ の指標は $H_{0}{ }^{\prime} / L_{0}$ による変化が今回 の指標よりも大きく表わされている。ただし，旧砕波指 標はこれから $H_{b} / h_{b}$ の值を計算してみると明らかなよ うに, $h_{b} / L_{0} \fallingdotseq 0.04$ で最大值 $H_{b} / h_{b} \fallingdotseq 0.84$ を取り, $h_{b} / L_{0}$ がこれよりも小さくなると $H_{b} / h_{b}$ の值が減少す るようになり，図一19の傾向とは一致しない。

ここで, 1. で触れた数值例, $T=9 \mathrm{sec}, H_{0}=5 \mathrm{~m}$, 水 底勾配 1/50 以下の砕波水深および砕波高の推定を 図一 21，22 を使って行なうと,つぎのようになる。

$$
\begin{aligned}
\frac{H_{0}}{L_{0}}= & \frac{5}{1.56 \times 9^{2}} \fallingdotseq 0.04, \\
& \frac{h_{b}}{H_{0}}=1.50 \quad \therefore h_{b}=7.5 \mathrm{~m} \\
& \frac{H_{b}}{H_{0}}=1.06 \quad \therefore H_{b}=5.3 \mathrm{~m}
\end{aligned}
$$

Iversen の実験指標から求めた值は, $h_{b}=5.6 \mathrm{~m}, H_{b}=$ $4.7 \mathrm{~m}$ であったから, 砕波水深の推定值は $34 \%$ 増大 し, 砕波高の推定值も $10 \%$ 増えることになる。

\section{5. あ と がき}

本報告で述べた砕波指標の整理は, i) 実験データに ついて波高減衰の補正を行なったこと, ii) $h_{b} / L_{0}$ が小 さくなるにつれて $H_{b} / h_{b}$ の比が増大する理論計算の結 果を基準值に採用したこと, iii) 有限振幅波の波高変化 に関する理論計算結果を参照して沖波諸元との関係を調 ベたこと,の 3 点に特徴がある。ただし, 理論計算結果 を基準值として参照してはいるものの，相当部分は実験 值に基づいており，ここに示した砕波指標の信頼度もか なり実験データの精度に左右される。

一般に, 砕波に関するデータは変動が大きいのが特徴
である。図一1 18 に用いたのはすべて実験データであ り，一定周期，一定波高の規則波を使って十分制御され た条件の下で求められたデータであるにもかかわらず, 実験值のばらつきは大きい。現地の観測值もデータに含 めれば, ばらつきはさらに大きくなる。もともと砕波の 現象は, 波が安定性を失なって波面が不連続となる限界 における現象であり，その不安定性の発現が外部条件の わずかの差によって左右される以上，こうしたデータの ばらつきは砕波現象の本質から見てある程度やむを得な いものといえよう。したがって，図一19２2 では，各 砕波指標として水底勾配ごとに，それぞれ 1 本の曲線で 示しているけれども，これは平均的な概略值を与えるに 過ぎず，個々のデータはこれから相当程度のばらつきを 示すことを考えておく必要がある。

また，砕波指標を実際の海岸における波に適用する場 合, 現地の波の不規則性が大きな問題となる。砕波帯内 における $H_{b} / h_{b}$ や $Y_{b} / h_{b}$ の特性であれば, 1 波ずつ切 り離して考えてみれば, データのばらつきは大きくなる けれども，平均的には 図一19，20 などを使うことがで きよう。しかし，沖の波と岸近くの波を 1 波ごとに対応 させることは，波の不規則性から考えて無意味なことで ある。したがって, 図一21，22 などの沖波諸元との関 係については，これがこのまま現地に適用できるか否か 問題が残されている。沖波の諸元として現行の設計法に したがって有義波を用い，砕波水深や砕波高を推定した としても, 実際の海岸の砕波は特定の水深だけで起こる のではなくて, 広い幅の砕波帯の中の各所で起こるもの であるから，どの地点の砕波水深や确波高を推定したこ とになるのが不明といわざるを得ない。こうした問題の 解明は, 波の不規則性を考慮した現地観測とその解析, あるいは不規則波水路による実験データの集積などを待 たなければならないであろう。

さらに，現地の波の不規則性の観点からは，たとえば $H_{1 / 3} / h$ が大きいときに波群中の波高分布が Rayleigh 分 布からはずれて分布幅がどのように狭くなるか，などが 実用上の大きな問題となろう。砕波に関する問題は, 今 後こうした波の不規則性との関連において検討が進めら れるのではないかと思われる。

\section{主要記号一覧表}

$h:$ 水深

$h_{b}:$ 砕波水深

$H_{b}$ : 砕波高

$H_{B M}$ : 限界設計波高（与えられた水深において最大の 波力をおよぼす波高)

$H_{0}$ : 沖波波高

$H_{0}{ }^{\prime}$ : 相当沖波波高 $=K_{r} \cdot H_{0}$ または $K_{f} \cdot H_{0}$ 


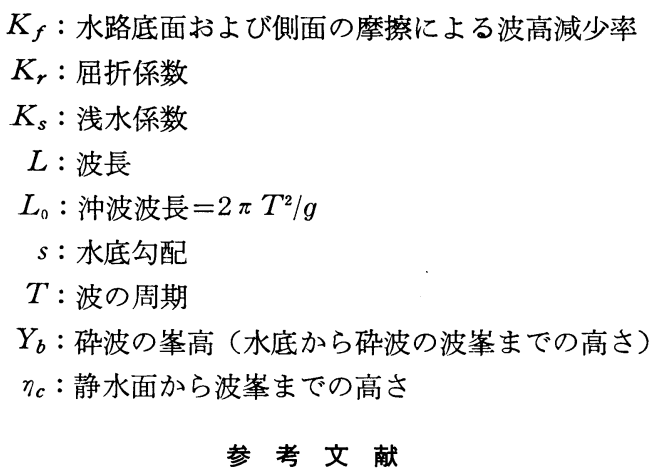

1) U.S. Navy Hydrographic Office : Breakers and surf : principles in forecasting, H.O. Pub. No.234, 1944.

2) Mason, M.A. : The transformation of waves in shallow water, Proc. 1 st Conf. Coastal Eng., Long Beach, 1950, pp. 22-32. (海岸工学 I, 丸善, 昭 30, pp. 23-36)

3) Munk, W.H. : The solitary wave theory and its application to surf problems, Annals New York Acad. Sciences, Vol. 51, 1949, pp. 376-424.

4) U.S. Army Coastal Engineering Research Center : Shore protection, planning and design, Tech. Rep. No. 4 (3 rd ed.), 1966, pp. 101-104.

5) Wiegel, R.L. : Oceanographical Engineering, Prentice Hall, 1964, p. 173.

6) Iversen, H.W. : Laboratory study of breakers, Proc. Symposium on Gravity Waves, U.S. National Bureau of Standard, Circular 521, 1951, pp. 9-32.

7) Iversen, H.W. : Waves and breakers in shoaling water, Proc. 3 rd Conf. Coastal Eng., Cambridge, 1952, pp. 1-2. (海岸工学 II, 丸善, 昭 30, pp. 487497.)

8) Michell, J.H. : On the highest waves in water, Phil. Mag., Ser. 5, Vol. 36, 1893, pp. 430-435.

9) McCowan, J.: On the highest wave of permanent type, Phil. Mag. Ser. 5, Vol. 38, 1894, pp. 351-358.

10) Miche, M. : Movements ondulatoires de la mer en profondeur constante ou décroissante, Annales des Ponts et Chaussées, Vol. 114, 1944, pp. 25-406.

11) Hamada, T. : Breakers and beach erosion, Rep. Transportation Tech. Res. Inst., Ministry of Transportation, No. 1, 1951, 165. pp.

12) Suquet, F., and A. Wallet, : Basic experimental wave researeh, Proc. Minnesota Int. Hydr. Convent ion, 1953, pp. 173-191.

13）土木学会: 水理公式集（昭和 38 年增補改訂版)，1963, 603. pp.

14)]!佐藤清一：漂砂に関する研究 (4) 一浅水表面波につい $\tau 一$, 土木研究所報告, 第 82 号, 1952.

15)岸力: 海岸堤防に関する研究 (4) 一進行波の砕波限 界一, 土木研究所報告, 第 91 号, 1955, pp. 43-50.

16）首藤伸夫: 有限振幅波について一高次級数解による進行波 の研波限界一, 土木研究所報告, 第 111 号, 1961, pp. 111-119.

17) Dean, R.G. : Breaking wave criteria, a study employing a numerical wave theory, Proc. 11th Conf. Coastal Eng., London, 1968, pp. 108-123.

18) Chappelear, J.E. : On the theory of highest waves, U.S. Army Beach Erosion Board, Tech. Memo, No. 116, 1959, 28. pp.
19) Yamada, H. : Highest waves of permanent type on the surface of deep water, Rep. Res. Inst. Applied Mech., Kyushu Univ., Vol. V, No. 18, 1957, pp. 37-52.

20) Yamada, H.: On the highest solitary wave, Rep. Res. Inst. Applied Mech., Kyushu Univ., Vol. V, No. 18, 1957, pp. 53-67.

21) Yamada, H. : Permanent grarity waves on water of uniform depth, Rep. Res. Inst. Applied Mech., Kyushu Univ., Vol. VI, No. 23, 1958, pp. 127-139.

22) Yamada, H., G. Kimura, and J. Okabe : Precise Determination of the solitary wave of extreme height on water of a uniform depth, Rep. Res. Inst. Applied Mech., Kyushu Univ., Vol. XVI, No. 52, 1968, pp. 15-32.

23) Yamada, H., and T. Shiotani : On the highest water waves of permanent type, Bull. Disaster Prevention Res. Inst., Kyoto Univ., Vol. 18. Pt. 2, No. 135, 1968, pp. 1-22.

24) Reid, R.O., and C.L. Bretschneider : Surface waves and offshore structure, Texas A. and M. Res. Foundation, Tech. Rep., 1953, 36. pp.

25) Goda, Y. : Wave forces on a vertical circular cylinder : experiments and a proposed method of wave force computation, Rep. Port and Harbour Res. Inst., Ministry of Transport, No. 8, 1964, 74. pp.

26) Mitsuyasu, H. : Experimental study on wave force against a wall, Rep. Transportation Tech. Res. Inst., No. $47,1962,39$. pp.

27）岸 力・庵原照太郎：海岸堤防汇関する研究（7）一波 の变形々砕讨波関する実験的研究一, 土木研究所報告, 第 95 号, 1958, pp. 185-197.

28）合田良実・原中祐人・北畑正記 : 直柱比衝く衝撃砕波力 の研究, 港湾技術研究所報告, 第 5 巻 6 号, 1966, $30 \mathrm{pp}$.

29）豊島 修・富永正照・橋本 宏: 砕波後の波の変形関 する実験的研究, 土木研究所報告, 第 133 号, 1968, pp. 121-129.

30) Bowen, A.J., D.L. Inman, and V.P. Simmons : Wave "set-down" and set-up, Jour. Geophysical Res., Vol. 73 , No. 8 , 1968, pp. 2569-2576.

31) Galvin, C.J.Jr. : Breaker travel and choice of design wave height, Jour. Waterways and Harbors Div., ASCE, Vol. 95, No. WW 2, 1969, pp. 175-200.

32）合田良実：構造物に働く波力, 1967 年度水工学墽する 夏期研修会講義集, 土木学会水理委員会, 1967 年, pp. 10-1 34.

33) Hall, M. A. : Laboratory study of breaking wave forces on piles., U.S. Army Beach Erosion Board, Tech. Memo., No. 106, 1958, 24. pp.

34) Le Méhauté, B., and L.M. Webb : Periodic gravity waves over a gentle slope at a third order of approximation, Proc. 9th Conf. Coastal Eng., Lisbon, 1964, pp. 23-40.

35) Koh, R.C.Y., and B. LeMéhauté : Wave shoaling, Jour. Geophysical Res., Vol. 71, No. 8, 1966, pp. 2005-2012.

36）岩垣雄一・酒井哲郎：有限振幅波の shoaling について (2), 第 15 回海岸工学講演集, 1968, pp. 10-15.

37) Iwagaki, Y. : Hyperbolic waves and their shoaling, Coastal Eng. in Japan, Vol. 11, 1968, pp. 1-12.

38) Laitone, E.V. : The second approximation to cnoidal and solitary waves, Jour. Fluid Mech., Vol. 9, Pt. 3,1960 , pp. $430 \sim 434$.

(1970. 3. 11 . 受付) 